\title{
Judit Friedrich
}

\section{TWIN ARTISTS OF NARRATION: PETER GREENAWAY AND JOHN BARTH}

In the following essay I will offer an overview of the roles of author and reader, of creator and audience, in the works of two Postmodernist artists, representative of two narrative - as well as reflective - branches of contemporary art: film and fiction. My method will be to present phenomena, concepts, and creative artists in pairs, in the hope that a demonstration of their similarities and differences will lead to a clearer understanding of the constituting elements.

Some of my premises may need explanation. Firstly, the art of film, a relatively recent development only a hundred years old in 1995, will be examined here as a form of art that arguably belongs to the realm of narration due to its fundamentally sequential mode of presentation. Another reason for its discussion in the present context is that film is a form that in many ways seems to have taken the place the novel had occupied in the attention of audiences for the previous two centuries.

Secondly, I consider Peter Greenaway as an author, rather than a director in the strict sense, since he makes his films himself from scriptwriting to producing, although with the assistance of experts at all stages (Greenaway, 1994).

Thirdly, the choice of Peter Greenaway, a distinguished representative of contemporary British film makers, and John Barth, a celebrated American novelist, is based on the observation that their works seem to share wellresearched Postmodern characteristics - especially viewed from a third point in Hungary. Evoking the magic word of intertextuality - the notion of the primacy of the interplay of texts within the mind of the reader over the isolated 
interpretation of the individual work - this comparative analysis is offered as one of a number of possible readings, or, better still, as a space for the free interplay of multiple texts.

Before addressing the problems of audience and authorship separately, a brief survey of some of the most striking general similarities of Barth's and Greenaway's attitudes toward art and artistic technique might be helpful. The most important parallel feature is the emphasis both Barth and Greenaway place on form and structure. This emphasis draws special attention to the artistic arranger of elements and creator of structures, that is, to the person, as well as the abstract concept, of the creative artist, who, however, is often presented in the disguise of intellectuals or game-players, usually counterbalanced by a contrasting group of characters interested in wealth and other less subtle forms of power.

Both Barth and Greenaway have a fascination with pre-19th- century ages: their references are definitely pre-Romantic, even neo- Baroque. They do not claim the place of the Romantic author-genius, they do not claim to be honest or truthful or spontaneous, nor are they objective Realist authors; they both acknowledge the artificiality of their works, their high level of structuralisation, and their commitment to foregrounding the patterns as well as the language they are using or creating for their works.

Barth is mainly interested in the 18th Century, which becomes clear not only from the setting of The Sot-Weed Factor $(1960,1967)$ but also through the revived 18th-century epistolary novel form of LETTERS (1979). On the other hand, Greenaway's favourite seems to be the 17th Century. The Draughtsman' Contract (1982) is set in 1694, the year of the establishment of the Bank of England (MOKÉP, 1989); there are obvious references to Shakespeare in Prospero's Books (1991); and we see the portrayal of a 17th-century theatre production in The Baby of Macon (1993). There are abundant visual references to 17 th-century Dutch painting, such as the re-vitalisation of Vermeer's paintings in Z0O (A Zed E Two Noughts, 1985), as well as the colours and imagery of Dutch painting present in The Cook, the Thief, His Wife and Her Lover (1989). Moreover, Greenaway's predilection for early baroque music underlies almost all of his films.

Both Barth and Greenaway are lost in counting and listing the ways of doing a single thing, which, once done, could be forgotten, but which not done presents countless possibilities, looms above the horizon, and stays with us. For 
Greenaway windows, telephones, bathrooms, and methods of murder 1 are phenomena to be catalogued or alphabetised, while Barth collects and displays methods of storytelling, narrative situations, and varieties of possible discourses.

Collecting seems to be an important Postmodern feature in general, as a way to avoid making a decision in favour of one piece, as well as a metaphor for the hoarding tendencies of society (cf. John Fowles' The Collector, 1963, or Bruce Chatwin's Utz, 19882). Similar attitudes in the creative process seem to result in producing variations, for example by presenting characters in several slightly different versions. Authors can multiply characters, for example, by recycling myths - such as Greenaway's version of the Virgin and Child in The Baby of Macon or Barth's versions of mythic heroes - facilitating a comparison of model and imitator, archetypal image and individual aspiration.

Another form of multiplication is the introduction of a basic fictional character in somewhat modified forms - a frequent device in Barth's works, also appearing as the three Cissies in Greenaway's Drowning by Numbers (1988) demonstrating the multiplication of the self in its different approaches to a problem, as well as in confrontation with its other versions.

A form of multiplication that almost resembles cloning is the doubling of characters by the introduction of twins several times over in both oeuvres, for further emphasis of the validity of simultaneous possibilities in any situation. This common interest in twins, illustrating questions of identity, is also the underlying inspiration for the following twin essays on audience and author.

\section{READERS AND AUDIENCES}

Both Barth and Greenaway are prominent, well-known creative personalities, and both have been accepted as leading Postmodernist artists who claim academic and popular attention alike. Yet both reward the analytical, even professional, audiences while supplying very strong effects most often used in popular forms of their genres, although their versions are more controversial and more extreme than the usual straightforward entertainment mainstream audiences might expect

\footnotetext{
1 Windows (1974), Dear Phone (1976), 26 Bathrooms (1985), and Drowning by Numbers (1988)

2 "I intended the article to be part of a larger work on the psychology - or psychopathology - of the compulsive collector." Chatwin,, 1988: 12
} 
(cf. the 208 rapes in Greenaway's The Baby of Macon, or the incestuous sexual relations in Barth's The Last Voyage of Somebody the Sailor, 1991). Both artists seem to have decided to cater to the highest and lowest common denominators at the same time, in one gesture presenting intellectual games and a naturalistic rendering of topics commonly believed to be exciting, such as sex, violence, or power. Yet both authors place considerable obstacles in the way of their audiences. Barth writes very long books on how problematic it is to tell a story, and Greenaway creates beautiful visual images of violence, greed, death, and decay. So the question arises: What kind of audiences do these works expect, or, indeed, postulate? Are the people who enjoy the superficial audience-trap features of gang rape the same people who appreciate foregrounded structural elements at the expense of a story? Are these works really talking to the pits and the gallery, as in the Elizabethan theatre?

In an attempt to examine the positions of audiences and authors in contemporary art, one could turn to theory and find that one fairly prominent line of literary theory from Plato to Stanley Fish concentrates on the reader.

Another approach could be to survey the role the reader has been invited to accept by the authors themselves while reading novels throughout the centuries. For the present purposes it may be enough, however, to establish that it is the implied reader, that is, the place the text constructs for the reader, which is to be examined, rather than the sociological categories the majority of a work's contemporary readers belonged to, or the response of later generations (cf. Montgomery et al. 1992:223 and Toolan 1988:77-80).

From this point of view, it is revealing to examine Roland Barthes' theory of writerly texts presented in $S / Z$ (1970) and put into practice in A Lover's Discourse (1977), where he requires the readers to read creatively, to supply a context for the utterances printed in the book, and, by themselves providing the images for his verbal archetypes, to co-produce the work with the author. Similarly, although more mechanically, B.S. Johnson's The Unfortunates (1969) needs the cooperation of the reader, who will determine the order in which the pages of the work are to be read.

These devices point in the direction of computer authorship, where interaction is possible as soon as the 'original' file is loaded on to the machine. Writers working in this direction deny the almighty position of the author and the necessity of a predefined meaning or moral in favour of the decisive powers of the reader, opening up various possibilities of writerly attitudes toward literature. 
An interesting example of how writerly reading works is the concept of the American women's romance writing club, where the borderlines between readers and authors are consciously blurred. Popular romance is written primarily for women, by women, so much so that male writers take female pseudonyms in order to fit the pattern. This is also a genre where repeated readability may not be a requirement (see any second-hand bookstall at church fairs or charity events except for possible favourites, these books are read once and are given away). To ensure an influx of new material as well as to encourage creativity, clubs have been formed (so one gathers from U.S. dailies, such as The Los Angeles Times) with names like the Women Writers' Association, where women come together to write popular romances. The guidelines for the genre are available even in very formal terms from certain publishers (for example, the British Mills \& Boon), and the participants are already familiar with them from their reading experiences. The members of these club come together to discuss works in progress as well as completed pieces, and the best works are published.

This is a truly writerly example - up until the point where one of the books is published and joins the ranks of the traditionally readerly books, since the writerly reader who has just turned into a writer may not write writerly texts, that is, may not leave much place for the reader of the new work, arguing, paradoxically, for the definitive power of the author. While writerly texts by definition require the reader's cooperation by reading, this cooperation is facilitated by the writer through the writing techniques employed. Writerly texts, therefore, are still primarily initiated by the author's input; the copyright also belongs to the author, and the co-producer readers' names do not appear on the title page.

The reader, let us remind ourselves, cannot be born without the author. In the case of the individual reading process the reader can be creative, but may not even have as defining a role as the author: interactive language teaching workbooks are also written by authors, and the similarity between various readings of a book will also have to be attributed to the author's work (having duly considered underlying cultural parameters). Besides, from offering an invitation for the reader to play it does not necessarily follow that the reader perceives the invitation as such and even accepts it, rather than turning away from the work as if the artist had breached a contract to offer easily attainable pleasures by substituting them with joyless fiction. 
If the role of the author is, after all, considered to be that of a source or a spring, it will be necessary to examine the actual techniques the two authors in question, Barth and Greenaway, use to construct, or at least handle, a reader or an audience.

Barth's decision is to avoid straightforward storytelling and to play with the roles of narrator and narratee instead. He does not invite the readers of his books to provide the material or take responsibility for it, but merely to analyse and appreciate his authorial skills while reading. The medium he uses allows this; the traditional physical book does not need more contribution from the reader than the actual reading. Barth seems to acknowledge this by concentrating on playing with the narrative voice and the roles of narratees within the book, rather than trying to induce any controlled activity by his readers external to his works.

Barth's writing about writing and storytelling shows traces of the analysis of his own works just being written. This attitude was already present to some extent in Henry Fielding's or Laurence Sterne's works, in the 'Dedicatory Epistle' of Walter Scott's Ivanhoe (1819), or in any apology by any author, but now it is foregrounded. It is not merely a concern with form, medium, or technique - it is also a concern with the person of the author. Barth writes as if he were reading and writing about what he is writing, thereby producing a metawriterly text, showing a critic's concern with a text he incidentally is the author of - or, alternatively, showing an extraordinary interest in the author. This latter aspect will be examined below, under 'Authorship', the counterpart to this essay, which will concentrate on problems arising around the author; for now, let us proceed with the self-effacing critic theory.

Writing for analysis, as academic authors often do, creates a narratee who is very much like a critic, such as mythology major female graduate student listeners in Chimera (1972); literary critics like Susan, the Associate Professor of American Literature and Creative Writing in Sabbatical: A Romance (1982); or library scientists like Katherine, Director of Folklore and Oral History in The Tidewater Tales: A Novel (1987). What is this critic-narratee supposed to do? Surely not interpret - we have the votes of Jonathan Culler, Michel Foucault, and Susan Sontag against interpretation, and Sontag is not alone with her opinion that "interpretation is the revenge of the intellect upon art" (1964, 1972:655). Interpretation and analysis, however, are different. Analysis is supposed to help the reader think and understand, to read more consciously - that is to say, to perceive more of the text and enjoy it more fully. The analytical critic characters 
in Barth's books in fact share the joys of living, loving, and storytelling with their narrator-heroes; they understand each other.

But what is the role of the external critic-reader in this game? Analysis seems to be the major form of justification for art nowadays; critics are the ones to offer immortality for artistic achievement, while 'best seller-dom' - the world of mass readership or the box-office hit - often seems to belong to a more ephemeral sphere. It is enough to have a few critics singing the praises of the masterful virtuosity of the author, as long as they praise it well and in the right places, even if some of them should follow Barth's method and write self-reflexive metacriticism ending in Barthian complaints about how futile it is for the critic to act out the role coded in the Postmodernist texts of the author discused.

The rest of the audience, however, may give up. The empowering of the reader actually puts a heavy burden on the recipient of the text. The reader has to make decisions, the reader is supposed to make sense of the text, the reader is invited to co-create the work - it seems like a job for trained professionals. Kids, don't try this on your own at home... If the special role of the magician-author disappears, will the magic stay with the readers? Will the reader work this hard for the Aristotelian catharsis? If the reader is not willing to play the game offered but chooses total passivity instead, to the point of the rejection of reading, thereby ceasing to be a reader, the Death of the Reader will be complete.

Are we, then, witnessing the birth of the critic at the cost of the death of both author and reader? As if to argue for the point, literature and English departments in U.S. colleges seem to concentrate increasingly on the teaching and production of theory. On the other hand, British university English departments have Media Studies and Communication Studies branching off of them, both showing a tendency to diminish the significance of literature, or at least to examine literature in a broader context. The analysis of films based on the appreciation of their narrative features, especially of film versions of established works of literature, is also becoming a practice employed within English departments. ${ }^{3}$ Encouraged by this trend, but discussing film as a different form of narration, rather than a popularising agent for literature producing twice-removed versions of books, I shall now examine the role Greenaway casts for the audience in his films in an embedded twin analysis to that of Barth's attitudes toward the reader.

3 e.g., at the University of Strathclyde, Glasgow; cf. Montgomery et al., 1992,, especially chapters on narration. 
Greenaway also seems to have a sharp eye on the audience, observing us in the role of watchers of his films. Similar to Barth's stories within stories, Greenaway has pictures within 'the pictures' (the film), and myth within all, problematising foreground and background and simultaneously showing layers of images physically as well as metaphorically. In The Draughtsman's Contract there are drawings presented in the process of their development; Drowning by Numbers features games complete with rules, explained as well as played out; in ZOO photographs and films are taken, shown, and viewed within the film; in Prospero's Books we have the books Shakespeare's play contains foregrounded, containing everything, but also have Shakespeare's play; and in The Baby of Macon there is a theatre with the film's characters as actors, thereby not only framing the story but also presenting the "all the world is a stage" Shakespearean notion.

Already in Z00 there is a strong tendency to point out that everybody who views is also viewed, possibly including the audience, but it is really in The Baby of Macon that the notion of the audience as an external body of observers is problematised, especially at the end of the film. As the carcass of the barn animal and the corpses of the Son of the Priest and the Sister of the Child are brought out on stage while the other actors take their curtain calls, the audience of the Theatre of Macon clap, until they turn around to bow towards the camera and another clapping audience, who in their turn turn around and bow ... In Hungarian cinemas people do not clap, but there is no doubt left that the audience is now to turn around and face their own audience in the world outside.

This case, however, is not just a matter of relativising roles - who is setting the rules, who is playing games, who has the power - as in previous films by Greenaway. In The Baby of Macon power games seem to involve the audience more directly.

Although The Draughtsman's Contract already showed general powerrelationships between the artist and the society he serves - he, as the Artist and the Intellectual are usually male characters in Greenaway's films - and unresolved mysteries remained, unsettling the viewers, the audience was still allowed to observe events discretely from the darkness of the auditorium. In contrast to the clear skies, green fields, and white sheep of The Draughtsman's Contract, however much framed by the Draughtsman's grid (and he in turn by the lords and ladies of the mansion), the general interior setting of The Cook, the Thief, His Wife and Her Lover brings the message 'home'. The way contemporary images - 
although with emphasis on features reminiscent of earlier periods - are presented (such as the destruction of the Intellectual and his Library, the Choir Boy and his fate, the death of Love as well as Lover, and the grossness of the Thief) strongly suggests that the director considers the Thief responsible for the destruction of all values other than material; and it is anybody's guess who or what is represented by the Thief: the nouveau riche, Mrs Thatcher and her policy of privatisation, or one's favourite social or political villain. Yet, unless one identifies with these characters in spite of the negative presentation, it is still possible to side with those who suffer, rather than with those who torture.

The Baby of Macon distributes blame more democratically. The Intellectual is an exception again - the Son of the Priest is mercifully killed fairly early on amid splashing blood and golden hay. But except for him, the Baby, and the Baby's wet nurse, nobody is blameless; all have their vices, even the audience - especially the audience, it seems towards the end. And at this point the patient movie-goer might voice some doubts.

What exactly does it mean if a film blames people in general? One may leave the cinema feeling that the world is a rotten place and that probably no nice people will survive here, not even oneself - or one may leave feeling like a miserable sinner, part of the evil crowd. The choice mainly depends on whether the individual viewer feels exempt from the blame, assuming the position of the impartial, outside observer, next to the First Observer of the events - that is, the director - or, lacking a positive hero(ine) to identify with, feels as part of the crowd to blame. This choice can be particularly interesting when people are beginning to realise that the way things happen in a country is not entirely independent of their own actions - at least not from their own votes in general elections, or in decisions whether their country should be part of the European Union.

The other question is that of the authority of the director who is spreading the blame. After all, we have seen a highly structured rendering of the world in a specific medium, not the world itself. And inasmuch as we have seen the director's vision of the world, his personal input is not to be underestimated, especially not in Greenaway's case where we have a director who started making films all by himself, wishing he could do the music as well (cf. Greenaway, 1994).

Is the placing of blame on the audience, then, part of the policy of empowering the reader, the principle materialising this time as sharing responsibilities between author and audience? The question of the 
interdependence of author and reader is very much in the focus in The Baby of Macon. It seems to be another death of the author/birth of the reader story. The mother of the child is to be of no importance: the child, the miracle, is adopted by the Sister to be put into the narrative framework of the Miracle of the Virgin Birth, for which she offers a creative reading indeed, in order to acquire fame and riches. The baby, however, is soon claimed by the Catholic Church, the copyright owner of the framework.

The Sister's function in the film seems to be that of a mediator, an interpreter in several senses of the word - functions usually attributed to the critic, a special reader of stories. The Sister is between the miracle and the audience; she not only realises the possible implications of the child's presence and 'reads' it as if it were a 'writerly text', but also speaks for the child.

But as a narrator of the story of the Miraculous Child, and the heroine of Greenaway's The Baby of Macon, having insisted on taking the role of the Virgin Mother ("Go through with it if you wanted the role so badly," say her colleagues later when holding her still in the serial rape scene), the Sister becomes the facilitator of the film, her role being necessary for the sake of the entertainment of the audience in the Theatre of Macon as well as for the audience of the movie, although for everybody concerned within the action, including herself, her ambitious role playing turns out to be fatal.

Thus her role seems to resemble that of a storyteller in the Barthian sense: one who tells her own story of being a fake, a follower of patterns, that is, one who is retelling someone else's story with the necessary changes for the present adaptation, thereby losing not only her identity but also her self. The situation is similar to that in Bellerophoniad, the third part of Chimera, where the narrative voice is that of Bellerus from the body of his twin brother Deliades who has tried to live out Bellerophon's life: "I was his mortal killer; therefore I became his immortal voice: Deliades I buried in Bellerophon, to live out in selfless counterfeit, from that hour to this, my brother's demigoddish life." (Chimera, p.318) The Sister's self tied with the Virgin as well as her virginity also has a parallel in Barth's The Last Voyage of Somebody the Sailor, where "self" is a euphemism for the heroine, Yasmin's virginity which she is supposed to defend with a knife she received as a gift: ' "To defend my ... self with," Yasmin said.' (The Last Voyage of Somebody the Sailor, p.425)

The audience has always been a primary mover of spectacles - for rituals, for the theatre, for the arts - but its role has been changing through the ages. Also, it 
has always had more and less sophisticated members. In The Baby of Macon the audience in the Theatre of Macon actively participate on several levels: they comment on the events (for example, they notice that the Sister at least did not torture the Child, while the Church probably does, otherwise how could they sell his tears and blood); they count, whenever necessary, a feature of significance for Greenaway, as is clear from his other films, such as The Draughtsman's Contract or Drowning by Numbers; but the aristocratic members are also active in eating and amusing themselves in ways other than those involved with the play.

But does this mean that the audience is the first cause of mishap, the final agency to blame, since it facilitates, even demands, the production of horror? The Sister, author of this particular adaptation of the Virgin and the Child story, was killed for her art.

How does, then, Greenaway, author of The Baby of Macon, hope to avoid responsibility for his film by turning the reproachful gaze of the camera toward the audience? If the audience do not get the prestige authors used to be given, why would they take the blame? If they do not receive the stories they expect from the storytellers, why would they go on listening? Greenaway, who is very much against the 'I am going to tell you a story' school of film making, as he writes himself, wants to create movies of thought, rather than movies of story (1994:2-3); Barth in Chimera also refused to tell stories. On what grounds do authors hope to survive if their attitudes toward their audiences are to shock them, to disappoint them, or to blame them? Perhaps it is time to reconsider the role of the author, the other of the twin concepts in this essay.

\section{AUTHORSHIP}

What is, then, the role of the author? Who is the author? And what is the author's aim, or hidden agenda, if any? Perhaps the most important fictional explorer of this problem is Vladimir Nabokov (cf. Pellérdi, 1994), but Barth is also deeply involved in problematising the questions of who is telling the story, who is acting it out, and which of these roles is primary, which one secondary or derivative.

Adaptations, including those of myths, are by definition secondary and derivative. But they also talk directly to the audiences because of their 
contemporary nature of delivery, much like advertising, commercial or political, which, as Barthes (1957) has pointed out, uses already established notions and images for present purposes.

If myth is considered as a form of expression, as Ernst Cassirer argued, claiming, "[M]yth is developed in order to objectify emotion,"4 we are indeed very close to T.S. Eliot's objective correlative.5 Authors of Postmodern adaptations of myth, however, give a subjective turn to emotions already objectified in myths or works of art, either by presenting mythic heroes as fallible humans or by portraying human beings heroically trying to follow mythic patterns. Both types of adaptation offer possibilities to express the author's quest for his own authorial identity, foregrounding in general the problems of creating and maintaining an identity, fictional, authorial, or heroic.

Problems of authorial identity possibly leading to a high degree of selfreferentiality have their earlier traces in art. In "A lírikus epilógja" (1908), Mihály Babits conceives identity as a form of limitation:

Csak én bírok versemnek hôse lenni, elsô s utolsó mindenik dalomban: a mindenséget vágyom versbe venni, de még tovább magamnál nem jutottam. 6

This attitude is more customary with lyric poets than with artists of narration, yet there are examples of authorial identity tied up with works of narrative fiction as well: Flaubert's words "Mme Bovary - c'est moi" seem to support the possibility of the projection of authorial identity into a novel. Furthermore, if the 19th-century model of Romantic lyric poetry expressing subjectivity and the Realist novel presenting an objective totality are considered as exceptions rather than the rules of their genres, it will become less surprising to find an overinflated authorial subjectivity in Postmodern fiction. Whether the result is still to be called a novel is another question.

4 reference to Ernst Cassirer, Language and Myth, 1946, quoted by Chapman and Egger, 170.

5 Washington Allston's term made famous by T. S. Eliot in an essay on Hamlet, 1919

6 Compelled to be the hero of my verse,

the first and last in every song I write,

I long to shape in them the universe, but nought beyond my self comes in my sight.

from "The Epilogue of the Lyric Poet", 1908, in: Mihály Babits, 21 Poems, transl. by István Tótfalusi, Budapest: Maecenas, 1988. 
Yet however inflated, even the Postmodern author could not claim to be an isolated, individual phenomenon, as Barthes would hasten to point out. The notion of the author being determined by various forces, such as a past (while determining and reshaping that past), became influential again around the turn of the century. It is present to varying degrees in Zola's biological and social determinism, Sigmund Freud's notions of the subconscious, or even T.S. Eliot's essay "Tradition and the Individual Talent", and Attila József's poem "A Dunánál" (1935), considering, from their different points of view, the interrelation of the individual and the past:

Tudunk egymásról, mint öröm és bánat.

Enyém a múlt és övék a jelen.

Verset írunk - ôk fogják ceruzámat

s én érzem ôket és emlékezem.?

This awareness of underlying forces influencing authorial identity is what then turns into its even more depersonalised version by the introduction of the notions of Barthes's codes, Jacques Derrida's assertion that there is nothing beyond the text, 8 and Julia Kristeva's intertextuality (Kristeva, 1966 and 1974), which latter can be observed in its most simple forms in the various techniques of allusions to, and adaptations of, myths and works of art, both abundant in Barth's and Greenaway's works.

The heavy reliance on mythology in W.B. Yeats' and Eliot's poetry, as well as James Joyce's prose fiction, also acknowledged a certain amount of derivativeness in literature. Relying on a tradition was a well-accepted merit in the Augustan age as well as in the Renaissance, and the return to it is part of the Modernist rejection of Romanticism. The notion of the Modernist artists using the mythical method while arranging and ordering their "heap of broken images" is expressed by Eliot. While Alan Wilde reminds us that Stanley Elkin denies the validity of Eliot's point for example in The Bailbondsman and The Living End, stating, "myth serves ... not to order chaos but to reveal it" (Wilde, 1981:159), this

7 "We know of each other, as pleasure and pain. / Mine is the past, and theirs is the present. / we are writing a poem - they direct my pen / And I can feel them and I remember" (rough translation by J. F.)

8 "there is nothing beyond the text - il n'y a pas de hors-texte": from Derrida's manifesto of deconstruction in Critical Inquiry, 1986, written as an answer to students following the publication of "Racism's Last Word", in Critical Inquiry, 1985. 
upinion, rather than invalidating Eliot's point, demonstrates the difference between a Modernist and a Postmodernist approach. What is important, however, is that myth is used in both cases as a method of presentation, a pattern, which can be and is, in fact, equally easily borrowed from songs, stories, paintings or murals and can also be created of colours, motifs, and images.

From a structural point of view, the Modernist heap of broken images now gives way to the Postmodern series. The series are sometimes numerical, such as counting in Greenaway's Drowning by Numbers or at his 1992 Vienna exhibition, where there were a hundred items, including 100 umbrellas as one item, as well as the catalogue of the exhibited items, which itself featured as number 100.9 The series may be organised according to the letters of the alphabet or, indeed, by following Darwin's notion of evolution, as in Z0O.

The arrangement of the elements may also vary. Sometimes they are presented in embedded structures and sometimes they rise as if in a spiral pattern, as in Barth's Chimera. The presentation often starts from an in medias res beginning, and proceeds on a linear journey ahead with a recapitulating narration including flashbacks and flashforwards, as in Barth's last four sailing stories and in Greenaway's use of the motif of games and death.

The series often consists of simultaneously existing variations, like the multiplied selves and counter-selves of the author in Barth's The Tidewater Tales or Once Upon a Time (1994), or contain serial variations, like most of the music for Greenaway's films, such as the variations on the songs "The Teddy Bears' Picnic" and "An Elephant Never Forgets" in Z00 or the ever-recurring short melodies and their variations in several of his other films, such as Drowning by Numbers. 10 It is interesting, however, that for the last sequence of the latter film, in the moment of imminent death, the music Greenaway chooses for his male intellectual to die by is not Postmodern Michael Nyman but chamber music for strings by W.A. Mozart, undermining his theoretical points in favour of emotional impact.

Foregrounding structuring elements and technical features, as well as the prominent use of myth, have an alienating effect, and as such have shown

9 also cf.: "Greenaway nem épít, legfeljebb konstruál. De inkább felsorol. Lineáris elme, a számok bûvöletében." ('Greenaway does not build, at best he constructs, but rather enlists. He has a linear mind, tied up in the magic of numbers.') (Lajta 9)

10 Michael Nyman, who composed the music for most of Greenaway's films, uses the terms "simple", "experimental", and "repetitive" for his music. (Nyman 1980) 
increasingly similar features to Bertolt Brecht's A- effects ever since High Modernism. Greenaway's lists, numbers, and occasional narrative voices in his short films and feature films alert the audience and do not allow them to immerse themselves in the flow of the story or images. In his short films Windows (1974), Dear Phone (1976), or the interminable A Walk Through $H$ (1978), where his drawings turn into maps of migratory birds' routes, he experiments with a combination of images and a narrator's voice, with the additional voice-over of several phone conversations in Dear Phone. Somebody is showing those images to us in a predetermined order, there is no 'natural flow' to the series of images - the less so since they are also variations on one theme, similarly to the way Somebody the Sailor decides to present information to us in a predetermined order, another series of variations on certain themes, in his stories of his quest for the truth about himself and about his beloved in Barth's The Last Voyage of Somebody the Sailor.

Greenaway has already experimented with the necessary skills in his television films, such as the non-narrative $M$ is for Man, Music, Mozart (1991) as well as the fragmentary Open University film Darwin (1992), which is arranged in 10 or so tableaux. Simultaneous frames are to be found in his A TV Dante: Cantos 1.8 (1988) and are then brought into focus and displayed for the featurefilm public in Prospero's Books, where productional innovations also abound. The technical experimentation that is so prominent in both Barth's and Greenaway's work, however, seems to serve other purposes, beyond a display of technical virtuosity: their attempts at patterning and arranging thoughts and images represent the world in ways that may be sufficiently different to shake stereotypical mindsets and world- views audiences may have.

Both Barth and Greenaway are interested in structuring larger units; they demonstrate how events can be connected by numbering, logic, evolution, linearity, mythological association, or by their relation to various forms of art. Yet they do not arrive at a final order out of chaos; moreover, they often destabilise various orders they create, thus emphasising the problems of part and whole, of element and organism. In the end, all foregrounding of arrangement seems to serve the purpose of alienation in the Brechtian sense, as well as reminders for the audience that they are watching artifices, products of artistic arrangement (if not necessarily of creativity), thereby drawing considerable attention to the arranger, the author himself. 
In films that make the governing conventions of film topical, such as the Twin Peaks11 television series or Top Secret/12, the camera and its viewpoint itself are presented by revealing their governing conventions. Greenaway in Z0O uses this type of visual self-reflexivity to draw special attention to the person behind the camera: even if the camera is taking automatic time-lapse photographs, he points out that there are watchful eyes following the events, and that even the watchers, such as the twins Oliver and Oswald taking the shots, are being watched. This emphasis on watchers and being constantly watched brings dark associations of Big Brother watching us into frightening proximity to the so-called 'free' West, carrying disillusioning messages about individual freedom for human civilisation of our praised European kind. And indeed we are watched and polled, if for nothing else, for someone to conduct their next advertising or political campaign more successfully.

It might be useful to emphasise the analogy between Brecht's A-effect and writerly texts. The audience or the reader is expected to do two things at a time: follow the action and allow for an alternative, so that nothing will be taken for granted or taken at face value. The fundamental aim of the A-effect is to make everything questionable. While the audience is still supposed to be naive as to the tricks performed on stage, once outside in 'real life' they are to be very much alert.

Another parallel feature of Brecht and Postmodernism working toward an alienation effect is a lack of belief in originality; in fact Brecht, too, believed in variation: he shows mirror image as well as mirror and provides a parody for all kinds of genre, including parody itself (cf. Honti 1982:374-378).

The question of parody is also interesting in connection with Postmodern adaptations. Is The Baby of Macon a parody of the Christ story? Are Barth's books parodies of the Arabian Nights, or Greek myths? I would say no - Greenaway's interest is to express fundamental feelings of loss, death, and decay, and Barth's is to celebrate life and make people read the works he supposedly parodies, while the interest of both authors in patterning things along old routes, whether the alphabet, counting, myths, or maps, seems to me to contradict parody as their

11 Twin Peaks (pilot TV film), David Lynch, United States, 1989; Twin Peaks (television series), various artists, US, 1990.

12 Top Secret!' Jim Abrahams, David Zucker, Jerry Zucker, US, 1984. 
dominant genre.13 They use familiar material, and they provide new variations for it; Barth works with language and Greenaway with pictures as a sculptor works with stone. Moreover, far from pointing out the controversial points of the models, Barth actually ridicules the followers, including himself. Although he acknowledges a possible streak of parody in his works, he seems to emphasise the comic quality of his approach: "If my reorchestration of the myths has an element of parody or even travesty in them, it's because while I take that subject very seriously indeed, I don't regard it as being necessarily a tragic or heroic business in our own lives. It also has a comic aspect." (Ziegler and Bigsby, 1982:30)

Elizabeth Dipple, a critic who seems to be wholeheartedly antagonistic towards authors like Barth whose works she calls metafiction rather than using the term Postmodernism, emphasises the ironic quality of these works: "Metafiction takes the reader's sophistication and complete absorption of genres from the past for granted," and she continues, "Its irony comes from the fact that it is referential to literature itself rather than to human experience." (Dipple, 1988:9)

Whether parody is accepted as a dominant technique of Postmodern adaptations, or, alternatively, whether the underlying structuring value of myths is considered as the basis of variation or adaptation, a certain amount of alienation is undeniably present through the sheer dichotomy of the allusion to the Already Known and the introduction of the Shockingly Different, which, while they support each other, also undermine each other's credibility.

Alienation techniques used by the Theatre of the Absurd work to show the absurdity of what is accepted as 'normal' in 'real life', such as waiting - beliefs hopes - routines - relationships - inertia in Samuel Beckett's Waiting for Godot (1952). Noticing the arbitrary or constructed quality of what we have grown up considering 'natural' is also one of the key messages of several contemporary theoretical trends, such as Deconstruction, Poststructuralism, New Historicism, and Feminism, which would all want to alienate mankind out of its follies.

In this context it is not surprising to find an attempt at the destabilisation of the almighty position of the author. But if everything is destabilised, desauthorised, why do such strong autobiographical and authorial presences appear as those of Barth and Greenaway, and why, or how, would it be possible

13 Zoltán Abádi Nagy also discusses irony and satire, rather than parody, in his book on Postmodernist American fiction in the 1960s. 
to give all authority to the reader? Are we to turn back to the reader again, having come full circle? Fowles, for example, has doubts about the powers of the reader, which becomes apparent when he quotes Antonio Gramsci's phrase "cultural hegemony" in an interview as "the very cunning and sophisticated systems of brainwashing that so-called democratic western societies have evolved to keep the ordinary man and woman passive and sheeplike" (Ziegler and Bigsby, 1982:115). In the same interview, Fowles also discusses the reader's freedom:

In an internal sense, textually, I do not think a novelist can offer freedom to his readers, however aleatory his technique, however many forks he offers, however many 'clues' he suppresses. This is especially true in narrative and character terms. On the other hand, I think there is some sort of metaphorical truth in the use of alternative situations that is, it suggests to the reader a possible method of escape in terms of her or his own life and its fictions and realities. It can't of course offer the actual

escape

$(1982: 118)$

He presents the reader's freedom and authority no less illusory than those of the author. In a sense he shows it as even more of an illusion, suggesting that it is not only the 'text' of the author that is to be deconstructed, but the 'text' of the reader as well, complete with the reader's history and unchallenged assumptions. The 'naive readers' are naive only inasmuch as they are unaware of their own level of determinism and the necessity to suppose as much for the author as for the reader.

In spite of all the news about the Death of the Author, there are some features still pointing towards the survival of authorship. One is the authority of the work and the situation of the presentation, which is made obvious in the theatre or the cinema by its constraints, if by nothing else. If the projector breaks down, one has to leave Mûvész Mozi and Z00 with the ostrich feathers and Caterina's zebra pants pending, while on an intercontinental flight one is a captive audience to the latest and least amusing film version of Alexandre Dumas's The Three Musketeers. All this shows the extent of the author's control over the audience, if ever so indirect. With books the reader had more personal freedom all along.

Another sign of the survival of authorship is that people do get paid for their intellectual products, even if very few of them can live on being an author only hence the increased importance of a development Dipple so poignantly describes in pointing out its main danger, its claustrophobia: "the creative writing seminar, 
where writers write for themselves and each other in a tight little coterie of mutual applause" (1988:11). Furthermore, a certain amount of originality is still required; authors have to have at least their own version of self- reflexivity or derivativeness.

Barth, for example, sees the same archetype worked out in all stories (Ziegler and Bigsby, 1982: 27-28):

The wandering hero re-enacts the history of a spermatozoon from the moment of ejaculation through the fertilization of the egg. And then the famous transcension of categories: spermatozoons are not male animals, and eggs are not female animals, but what has male aspects and what has female aspects come together into a creature that transcends the categories both of the egg and the sperm, and is both and neither. There is a COINCIDENTIA OPPOSITORUM, if there ever was one! Then the magic transformation flight in that third quadrant of the mythic cycle (acc. to Jung, Campbell, Raglan and company) is really just the first law of embryology: ontogeny recapitulating phylogeny. The reascent across the threshold would be birth, etc. In short, my story 'Night-Sea Journey'.

In this mythic story of the death and rebirth of wandering heroes the point of death is also a point of birth, a passage where the beginning is the end, such as the ones in The Last Voyage of Somebody the Sailor. Therefore the death, birth, or rebirth of the author or reader might be seen as part of a process, of a series of transformations, in which the self-reflexivity of the author is characteristic of merely one phase, where the work, instead of celebrating the creative genius of the author, is devoted to the depiction of the author (cf. "A Mester" in Péter Esterházy, Termelési- regény (kisssregény), 1979) at work, like a painter's selfportrait at the easel. But even those self-reflexive or even narcissistic portraits have the eyes watching the viewer dominate the picture, like Tivadar Csontváry Kosztka's, which brings us to the watcher-watched problem so important in Greenaway's films.

The poststructuralist death of the author is a very different view from the Postmodern narcissistic author, both being different from the sculptor of the Viennese Stephansdom or Alfred Hitchcock making cameo appearances in his films, who sign their works with their own images, much like a book cover featuring the portrait of the author.

But what happens if the writer keeps writing mainly about himself, if the painter paints himself only? If other motifs disappear, if the image becomes 
exceedingly self-referential? One path from here leads through increasingly dominant autobiographical references toward fictional autobiography, such as Barth's Once Upon a Time, where, however, stylisation reappears as soon as the concern with the authorial self has been offically established by the announcement of producing an autobiography.

A.P. Chekhov's Of the Dangers of Smoking, a one-act, one- actor play from the very beginning of the 20th century, is a play about speaking, where Chekhov makes his character give a public speech and problematise speaking in public, simultaneously foregrounding contentless form and the possible contradiction of topic and presentation. The character has trouble making his speech, yet he succeeds in making a speech about his troubles - just like Barth with his stories about being unable to tell a story, writing by exploring the causes of the lack of ability to write. But one can tell very few stories this way to the same audience.

The term intellectual property may be disappearing from our actively used imagery, like the romantic figure of the author did, and in these terms the authorgod may have indeed died (in spite of the media's attempts at maintaining these images). Nevertheless, the creative personality who will inspire others through the creation of a work of art will survive - perhaps along the lines indicated in Barth's later works, whereby the author's pleasure in creation is shared, even doubled, by the anticipation, rather than the rejection, of that of the reader. The interplay of the author and reader still is a process offering most versatile results. Originality in ideas, whether to start a business, to produce a work of art, to create an image, or to tell a story, continues to be very much in vogue today. In The Last Voyage of Somebody the Sailor even Death is willing to take age-old Scheherazade only if she tells him a new story. There is still a market for novelties - even for novels.

\section{REFERENCES}

Abádi Nagy Zoltán: Válság és komikum: $A$ hatvanas évek amerikai regénye. Budapest: Magvetô (Elvek és utak), 1982.

Barthes, Roland: Mythologies, selected and transl. by Annette Lavers, London: Jonathan Cape, 1973 (1957). 
Barthes, Roland: S/Z, transl. by Richard Miller, London: Jonathan Cape, 1975 (1970).

Barthes, Roland: A Lover's Discourse: Fragments, transl. by Richard Howard, London: Jonathan Cape, 1978 (1977).

Chapman, Simon and Egger, Garry: "Myth in cigarette advertising and health promotion", in: Language Image Media, ed. by Howard Davis, Paul Walton. Chatwin, Bruce: Utz. London: Jonathan Cape, 1988.

Dipple, Elizabeth: The Unresolvable Plot: Reading Contemporary Fiction. New York and London, Routledge, 1988.

Greenaway, Peter: (interview with), in: Peter Greenaway korai rövidfilmjei, Budapest: Budapest Film, 1994.

Honti Katalin: "Brecht és Ljubimov", Világosság XXIII (1982), No6

Kristeva, Julia, Word, Dialogue and Novel (1966), transl. by Alice Jardine, Thomas Gora, Léon S. Roudiez, in: Léon S. Roudiez, ed: Desire in Language: $A$ Semiotic Approach to Literature and Art. Oxford and New York: Blackwell, Columbia, 1980.

Kristeva, Julia: Revolution in Poetic Language, transl. by Margaret Waller, Introduction by Léon S. Roudiez, New York: Columbia UP, 1984 (1974).

Lajta Gábor: "Világszertár", Filmvilág vol. XXXVI, No1, 1993 január.

MOKÉP: MOKÉP Rota 170/89 (information sheet on) The Draughtman's Contract. Budapest: Magyar Filmintézet, 1989.

Montgomery, Martin, Alan Durant, Nigel Fabb, Tom Furniss, Sara Mills: Ways of Reading. London, New York: Routledge, 1992.

Nyman, Michael: "Against Intellectual Complexity in Music" (1980), in: Docherty, Thomas, ed. \& introd., Postmodernism: A Reader. New York, London: Harvester Wheatsheaf, 1993.

Pellérdi Márta: Biography and Artifice in Vladimir Nabokov's English Novels, "kandidátusi" (PhD) dissertation. Budapest, 1994.

Sontag, Susan: "Against Interpretation" (1964), in: David Lodge, ed: 20th Century Literary Criticism: A Reader. London: Longman, 1972.

Toolan, Michael J: Narrative: A Critical Linguistic Introduction. London, New York: Routledge, 1988.

Wilde, Alan: Horizons of Assent: Modernism, Postmodernism, and the Ironic Imagination. Baltimore: Johns Hopkins University Press, 1981. 
Ziegler, Heide, and Christopher Bigsby, eds: The Radical Imagination and the Liberal Tradition: Interviews with English and American Novelists. London: Junctions Books Ltd., 1982.

\section{PETER GREENAWAY - SELECTED FILMOGRAPHY}

Windows, 1974

Dear Phone, 1976

A Walk Through H, 1978

The Draughtsman's Contract, 1982

Making a Splash, 1984

26 Bathrooms, 1985

A Zed and Two Noughts, 1986

The Belly of an Architect, 1987

Drowning by Numbers, 1988

A TV Dante Cantos 1-8, 1988

The Cook, The Thief, His Wife and Her Lover, 1989

Prospero's Books, 1991

M is for Man, Music, Mozart, 1991

Darwin, 1992

The Baby of Macon, 1993

\section{WORKS BY JOHN BARTH}

The Floating Opera, 1956.

End of the Road, 1958.

in Hungarian: $A z$ Ut vége: regény, transl. by Gyula Tellér, Budapest: Európa (Modern Könyvtár), 1970.

The Sot-Weed Factor, 1960, revised version 1967.

Giles Goat-Boy, 1966.

Lost in the Funhouse: Fiction for Print, Tape, Live Voice, 1968, in Hungarian: Bolyongás az elvarázsolt kastélyban: Széppróza nyomtatásra, magnóra és élôbeszédre, transl. and afterword by Zoltán Abádi Nagy, Budapest: Európa (Modern Könyvtár), 1977. 
Chimera, 1972 (National Book Award 1973). edition used: Greenwich, Conn: Fawcetc Crest, 1973.

LETTERS, 1979.

Sabbatical: A Romance, 1982.

The Friday Book: Essays and Other Nonfiction, 1984.

The Tidewater Tales: A Novel, 1987.

The Last Voyage of Somebody the Sailor, 1991. edition used: New York, London: Anchor (Doubleday), 1992.

Once Upon a Time, 1994.

\section{CRITICISM ON JOHN BARTH IN CHRONOLOGICAL ORDEK}

Joseph, Gerhard: Jobn Barth. Minneapolis, University of Minnesota Press, 1970.

Morrell, David: John Barth: An Introduction. University Park, London, Pennsylvania State University Press, 1976.

Waldmeir, J.J., ed: Critical Essays on John Barth. Boston, Mass: G.K. Hall and Co., 1980.

Hutcheon, Linda: Narcissistic Narrative: The Metafictional Paradox. New York, London: Methuen, 1980.

Harris, Charles B: Passionate Virtuosity: The Fiction of John Barth. Urbana, Chicago: University of Illinois Press, 1983.

Ziegler, Heide: John Barth. London, New York: Methuen (Contemporary Writers Series), 1987.

Fogel, Stan, and Slethang, Gordon: Understanding John Barth. University of South Carolina Press, 1990.

Schull, Max F: The Muses of John Barth: Tradition and Metafiction from Lost in the Funhouse to The Tidewater Tales. Baltimore, London: Johns Hopkins University Press, 1990. 


\section{THE \\ ANACHRONIST}

\section{5}

a collection of papers

Department of English Studies Sehool of English and American Studies Eötvös Loránd University (ELTE) BUDAPEST 